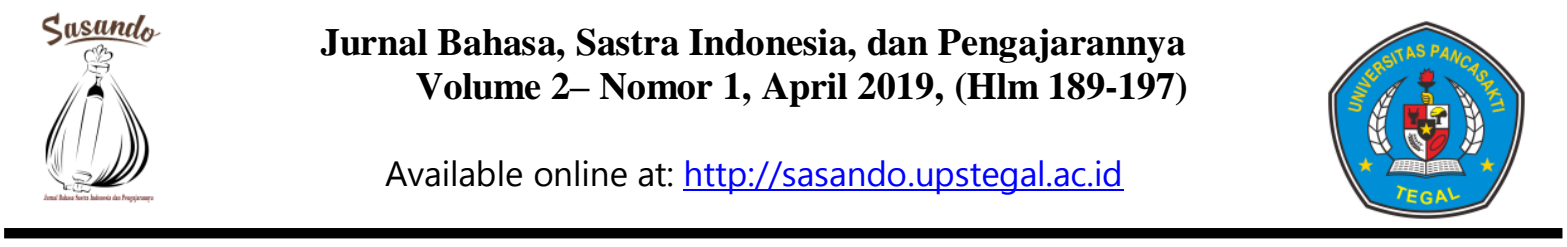

\title{
KALIMAT EFEKTIF DALAM KARYA ILMIAH MAHASISWA POLITEKNIK NEGERI PADANG
}

\author{
Welsi Haslina ${ }^{1}$, Afrini Rahmi ${ }^{2}$ \\ ${ }^{1}$ PROGRAM STUDI AKUNTANSI \\ POLITEKSI NEGERI PADANG \\ welsih@yahoo.com \\ ${ }^{2}$ PROGRAM STUDI PENDIDIKAN BAHASA DAN SASTRA INDONESIA \\ STKIP PGRI SUMATERA BARAT \\ afrini@stkip-pgri-sumbar.ac.id
}

\begin{abstract}
Penelitian ini dilatarbelakangi oleh pentingnya kemampuan menggunakan kalimat efektif dalam karangan ilmiah. Karangan ilmiah sebagai bentuk komunikasi tulis yang disampaikan secara tidak langsung mengharuskan penulis menyampaikan pokok informasi secara jelas dan tepat, sehingga tidak menimbulkan ambiguitas dan kerancuan makna. Kalimat yang ambigu dan rancu akan menimbulkan salah penafsiran bagi pembaca yang mengakibatkan pesan yang ingin disampaikan kepada pembaca tidak dipahami dengan sempurna. Populasi penelitian ini adalah seluruh laporan tugas akhir mahasiswa Politeknik Negeri Padang yang diserahkan ke perpustakaan selama kurun waktu satu tahun yaitu tahun 2009. Berdasarkan data dan informasi yang diperoleh dari kepala perpustakaan PNP diketahui bahwa jumlah laporan tugas akhir yang masuk selama tahun 2009 berjumlah 575 judul laporan tugas akhir. Hasil penelitian menunjukkan bahwa kalimat efektif yang digunakan mahasiswa Pilteknik Negeri Padang dalam mnulis kalimat efektif masih rendah dalam kehematan kata dan kelogisan bernalar.
\end{abstract}

Kata kunci: kalimat efektif, karangan ilmiah

\section{Abstract}

This research is motivated by the importance of the ability to use effective sentences in scientific essays. Scientific essays as a form of written communication delivered indirectly require the author to convey the information clearly and precisely, so as not to cause ambiguity and confusion of meaning. Sentences that are ambiguous and ambiguous will lead to misinterpretation for the reader, which results in the message to be conveyed to the reader not perfectly understood. The population of this research is all the final assignment reports of the Padang State Polytechnic students that were submitted to the library for one year, namely in 2009. Based on the data and information obtained from the Padang State Polytechnic library heads, it was found that the number of final assignments in 2009 was 575 thesis. The results showed that effective sentences used by Padang State Pilteknik students in writing effective sentences were still low in word efficiency and logical logic.

Keyword: effective sentence, scientific essay 


\section{Pendahuluan}

Politeknik Negeri Padang (PNP) merupakan lembaga pendidikan vokasi (pendidikan yang melatih peserta didik untuk suatu keterampilan atau pekerjaan tertentu) yang menghasilkan tenaga kerja terampil dan siap pakai pada suatu bidang keahlian. Dalam rangka menyiapkan calon lulusan yang berkompetensi pada bidang keahliannya, setiap mahasiswa PNP diharuskan membuat laporan tugas akhir. Tugas akhir merupakan salah satu syarat untuk menyelesaikan pendidikan program Diploma III pada semua program studi atau jurusan yang ada di PNP. Hal ini tercantum pada Peraturan Akademik PNP Bagian Keenam tentang Tugas Akhir dan Ujian Tugas Akhir Pasal 18 ayat pertama yang menyatakan mahasiswa pada semester VI diharuskan membuat tugas akhir (2008:14).

Tugas akhir yang ditulis mahasiswa berupa karangan ilmiah merupakan wujud akumulasi pengetahuan yang telah diterima oleh mahasiswa dalam 5 (lima) semester tatap muka perkuliahan. Arifin (2000:1) menyatakan bahwa karangan ilmiah menyajikan fakta dan ditulis menurut metodologi penulisan yang baik dan benar. Lebih lanjut dikatakan bahwa karangan ilmiah harus ditulis secara jujur dan akurat berdasarkan kebenaran tanpa mengingat akibatnya. Maryadi (2000:15) menyatakan bahwa karya ilmiah adalah suatu karya yang memuat dan mengkaji suatu masalah tertentu dengan menggunakan kaidah-kaidah keilmuan. Maksud dari kaidah-kaidah keilmuan adalah karya ilmiah menggunakan metode ilmiah untuk membahas permasalahan, menyampaikan kajian dengan menggunakan bahasa baku dan tata tulis ilmiah. Karya ilmiah bisa berupa makalah, artikel ilmiah, laporan akhir, naskah publikasi, dan laporan penelitian yang berupa skripsi, tesis, dan karangan ilmiah dapat dinyatakan sebagai sebuah tulisan yang memaparkan ilmu pengetahuan. Bahasa yang digunakan dalam karangan ilmiah adalah bahasa tulis. Bahasa tulis memiliki ciri yang berbeda dengan bahasa lisan. Bahasa tulis yang digunakan untuk tulisan ilmiah adalah bahasa tulis baku dan ragam ilmu pengetahuan. Bahasa tulis ragam ilmu pengetahuan adalah bahasa yang mempunyai ciri-ciri (1) pilihan kata dan peristilahan yang tepat, (2) kalimatnya efektif dan penataannya dalam paragraf baik, (3) penalaran dan sistematikanya bagus, (4) pemaparan dan gaya bahasanya menarik (Markhamah, 2000:138).

Suyanto (2009:25) menjelaskan karangan ilmiah merujuk pada karya penulisan yang berlandaskan pada metodologi ilmiah atau keilmuan tertentu. Bahasa karangan ilmiah, biasanya menggunakan kata, istilah, ungkapan, dan gaya bahasa yang maknanya bersifat denotasi, yaitu tepat dan jelas supaya tidak disalahartikan dengan makna-makna lain. Dengan kata lain, sebuah karangan ilmiah harus bersifat objektif, jujur, dan tepat.

Hasil penulisan yang dilakukan oleh mahasiswa PNP yang berupa laporan tugas akhir merupakan laporan ilmiah yang menginformasikan tentang kajian terhadap fakta-fakta sehingga dapat disebut ilmu pengetahuan. Ilmu pengetahuan yang disampaikan dapat dijadikan sebagai referensi oleh masyarakat banyak, terutama mahasiswa yang mempunyai disiplin ilmu terkait dalam rangka mengembangkan wawasan dan menambah ilmu pada bidang keahlian yang sama. Laporan tugas akhir tersebut kemungkinan dibaca oleh banyak pihak sehingga penulisannya harus menggunakan bahasa keilmuan yang 
mempunyai ciri logis, tidak berkontradiksi, dan empiris serta terhindar dari kesalahan

penggunaan bahasa. Kesalahan-kesalahan berbahasa itu dapat menimbulkan salah pengertian dan salah pemahaman, sehingga akan terjadi salah pemindahan ilmu. Selain itu, kesalahan berbahasa juga dapat membuat pembaca tidak memahami maksud yang ingin disampaikan penulis.

Kesalahan berbahasa yang terjadi salah satunya adalah penggunaan kalimat efektif. Kalimat efektif merupakan suatu jenis kalimat yang dapat memberikan efek tertentu dalam komunikasi. Efek yang dimaksud adalah kejelasan informasi. Ciriciri kalimat yang efektif adalah (1) kelengkapan, (2) kesejajaran, (3) kehematan, dan (4) variatif (Mustakim, 1994:85). Ciri yang sama disampaikan juga oleh Akhadiah (1988:116) yaitu kalimat efektif didefinisikan sebagai kalimat yang benar dan jelas, sehingga dengan mudah dipahami orang lain secara tepat. Kelengkapan unsur sebuah kalimat sangat menentukan kejelasan sebuah kalimat. Oleh sebab itu, sebuah kalimat harus memiliki paling kurang subjek dan predikat. Kalimat yang lengkap ini harus ditulis sesuai dengan aturan-aturan ejaan yang disempurnakan, dan kata-kata yang digunakan dalam bentuk kalimat harus dipilih dengan tepat.

Atmazaki (2009:71) menyebutkan bahwa kalimat yang digunakan untuk menyampaikan gagasan hendaklah disusun secara efektif. Kalimat yang efektif tidak memerlukan banyak kosakata, tetapi dengan sedikit kata yang tersusun dengan apik, sesuai dengan pola kalimat yang benar menurut tata bahasa, dapat menembus pikiran pembaca dengan tepat. Kalimat yang tidak efektif terjadi oleh berbagai sebab, dengan ciri (1) kalimat yang tidak lengkap,
(2) kalimat mubazir, (3) kalimat tidak baku, (4) kalimat tidak teratur, (5) kalimat bermakna ganda, dan (6) kalimat tidak bernalar.

\section{Keefektifan kalimat sangat} menentukan dalam berbahasa. Suatu kalimat akan dapat dikatakan efektif apabila apa yang dihasilkan dalam bentuk kalimat sesuai dengan apa yang dipikirkan. Sebaliknya, suatu kalimat tidak efektif apabila kalimat sebagai wujud apa yang dipikirkan tidak sesuai dengan apa yang ada dalam pikiran seseorang. Salah satu ciri kalimat efektif adalah hemat berbahasa. Kehematan itu dapat dilakukan dengan penggunaan kata-kata sesuai dengan bobot makna (Ruskhan, 2007:125).

Penggunaan kalimat efektif dalam sebuah karangan ilmiah dapat membatu penulis menyampaikan informasi berupa gagasan dan pengetahuan secara tepat kepada pembaca. Penggunaan kalimat yang tidak efektif dalam karangan dapat menyebabkan ambiguitas dan kerancuan pemaknaan. Hal tersebut dapat mnegakibatkan kesalahan penafsiran terhadap informasi yang diperoleh dari bacaan. Kalimat yang digunakan dalam karangan ilmiah harus berupa kalimat ragam tulis baku. Kalimat ragam tulis baku disebut kalimat efektif. Kalimat efektif yaitu kalimat yang memenuhi kriteria jelas, sesuai dengan kaidah, ringkas, dan enak dibaca (Arifin, 2000:84). Menurut Semi (2009:218) berhasil atau tidaknya sebuah tulisan ditentukan oleh dua faktor, yaitu (1) bagaimana gagasan ditata dan diorganisasi, (2) bagaimana pemanfaatan perangkat kebahasaannya. Perangkat kebahasaan menyangkut dua hal yakni ejaan dan kalimat efektif. Kalimat efektif adalah kalimat yang memenuhi sasaran, mampu menimbulkan pengaruh, meninggalkan kesan, serta ditulis 
dengan akurat, jelas, dan singkat. Kalimat efektif mempunyai ciri-ciri sebagai berikut:

(1) sesuai dengan pola kalimat bahasa Indonesia yang benar, (2) sesuai dengan tuntutan bahasa baku, (3) mudah ditangkap maksudnya atau jelas, (4) ringkas dan

hubungan yang baik (koherensi) antara kalimat satu dengan kalimat lain, (6) kalimat yang digunakan harus bervariasi, serta (7) tidak ada unsur yang tidak berfungsi.

\section{Metode Penelitian}

Jenis penelitian ini adalah penelitian kualitatif dengan metode deskriptif analisis.. Penelitian ini menguraikan tentang penggunaan bahasa Indonesia pada laporan tugas akhir mahasiswa PNP terutama dalam penggunaan kalimat efektif.

Populasi penelitian ini adalah seluruh laporan tugas akhir mahasiswa PNP yang diserahkan ke perpustakaan selama kurun waktu satu tahun yaitu tahun 2009. Berdasarkan data dan informasi yang diperoleh dari kepala perpustakaan PNP diketahui bahwa jumlah laporan tugas akhir yang masuk selama tahun 2009 berjumlah 575 judul laporan tugas akhir.

Jumlah sampel pada penelitian ini ditetapkan sebanyak 57 judul laporan tugas akhir mahasiswa Politeknik Negeri Padang. Sampel minimal pada penelitian deskriptif adalah $10 \%$ dari jumlah populasi. Jumlah itu pula yang ditetapkan menjadi sampel pada penelitian ini. Namun, seorang peneliti dapat mengambil sampel lebih dari ketentuan itu sesuai dengan kebutuhan penelitian. Laporan tugas akhir yang ditetapkan sebagai sampel pada penelitian ini mewakili setiap jurusan yang ada di Politeknik Negeri Padang, yaitu 10\% dari jumlah yang ada pada setiap jurusan.
Pengambilan sampel pada penelitian ini dilakukan secara acak dengan menggunakan teknik simple random sampling. Teknik ini dapat digunakan karena anggota populasi dianggap homogen yang mengandung satu ciri. Peneliti memberikan kesempatan yang sama pada tiap-tiap subjek untuk diambil sebagai anggota sampel, artinya seluruh laporan tugas akhir mahasiswa diyakini tingkat kerepresentatifan dan tingkat kevalidan sampel. Sampel diambil dengan melakukan lot pada setiap populasi. Laporan tugas akhir yang ada dalam daftar perpustakaan diberi nomor dan dilot sesuai dengan jumlah yang dibutuhkan untuk setiap jurusan dan ditetapkan sebagai sampel penelitian ini.

Pada penelitian ini, peneliti merupakan instrumen utama yang secara langsung mengumpulkan semua data kesalahan penggunaan bahasa yang dibutuhkan. Kesalahan penggunaan bahasa pada penelitian ini meliputi kesalahan ejaan, diksi, dan kalimat efektif. Peneliti adalah instrumen kunci atau human instrument.

Teknik pengumpulan data dilakukan dalam beberapa tahap. Pada tahap awal, penulis minta izin pada Kepala UPT. Perpustakaan Politeknik Negeri Padang untuk melihat dan mendapatkan data laporan tugas akhir mahasiswa tahun 2009 yang terdapat pada buku agenda laporan tugas akhir. Selanjutnya, laporan tugas akhir mahasiswa yang terpilih sebagai sampel penelitian difotokopi. Setiap sampel yang terpilih diberi nomor urut dengan menggunakan angka biasa (angka Arab) yang disertai dengan kode jurusan.

Pada penelitian ini teknik analisis data yang dilakukan adalah (1) data penggunaan bahasa yang telah dihimpun pada tabel rekapitulasi, masing-masingnya ditabulasikan sesuai dengan aspek kajian 
kalimat efektif. (2) Tabulasi data memberikan gambaran tentang jumlah data yang dapat dideskripsikan secara terperinci dan sistematis sesuai dengan acuan yang digunakan, serta sekaligus masing-masing data dievaluasi. (3) Pengolahan data secara kuantitatif untuk mendapatkan persentase ketepatan pemakaian kalimat efektif dengan menggunakan rumus sebagai berikut: ${ }^{\mathrm{f}} / \mathrm{n} \mathrm{X}$ $100=\%($ Sudjana, 2001:129), di mana $\mathrm{f}$ adalah jumlah kalimat yang benar dan $n$

adalah jumlah penggunaan (Sudjana, 1996:179). Selanjutnya, untuk tingkat pencapaian secara kualitatif dilakukan dengan menafsirkan angka persentase ke dalam rentang yang sudah ditetapkan. Rentangan yang digunakan adalah penilaian lima kategori seperti yang dilakukan oleh Arikunto (2009:269).

\section{Hasil dan Pembahasan}

Data penelitian ini adalah semua pemakaian bahasa yang diwakili oleh kalimat-kalimat dalam penulisan laporan tugas akhir mahasiswa Politeknik Negeri Padang. Jumlah laporan tugas akhir yang dijadikan sebagai data penelitian adalah 57 judul laporan tugas akhir, yaitu $10 \%$ dari jumlah data laporan tugas akhir tahun 2009. Data bahasa diambil dari bagian pendahuluan setiap laporan tugas akhir mahasiswa Politeknik Negeri Padang.

Seluruh data penelitian diberi nomor urut dan kode dokumen berdasarkan jurusan dari laporan tugas akhir. Jurusan Teknik Mesin terdiri atas enam judul laporan tugas akhir diberi kode dokumen 01. M-01 hingga 06. M-06, Jurusan Teknik Sipil dengan kode 07. S-01 hingga 12. S-012, begitu seterusnya untuk jurusan Teknik Listrik dengan kode 13. L-01 hingga 18. L-6, jurusan Teknik Elektronika (EC), Teknik Telekomunikasi
(TC), Jurusan Akuntansi (AK), Jurusan Administrasi Niaga (AN), serta jurusan Teknologi Informatika (TI).

Kalimat-kalimat yang terdapat dalam laporan tugas akhir mahasiswa Politeknik Negeri Padang dihitung dan dijadikan sebagai data bahasa pada penelitian ini. Setelah seluruh sampel penelitian dihitung, diketahui terdapat 2207 kalimat yang menjadi data penelitian. Rincian jumlah kalimat pada setiap laporan tugas akhir yang dijadikan sampel dapat dilihat pada tabel berikut ini

Tabel 1. Rincian Jumlah Kalimat yang Menjadi Data Penelitian

\begin{tabular}{|l|l|l|}
\hline 48. & 48. TI-07 & 21 \\
\hline 49. & 49. TI-08 & 47 \\
\hline 50. & 50. TI-09 & 43 \\
\hline 51. & 51. TI-10 & 36 \\
\hline 52. & 52. TI-11 & 35 \\
\hline 53. & 53. TI-12 & 23 \\
\hline 54. & 54. TI-13 & 36 \\
\hline 55. & 55. TI-14 & 38 \\
\hline 56. & 56. TI-15 & 55 \\
\hline 57. & 57. TI-16 & 28 \\
\hline & Total Data Kalimat & 2207 \\
\hline
\end{tabular}

.Kesalahan kalimat efektif terjadi pada keseluruhan kalimat yang dijadikan data bahasa. Kesalahan terdiri atas kesalahan struktur kalimat, kehematan kata, dan kelogisan penalaran. Jumlah kesalahan adalah 2207 atau $100 \%$.

Penggunaan kalimat efektif pada penulisan laporan tugas akhir mahasiswa Politeknik Negeri Padang dibatasi pada tiga aspek bahasan, yaitu struktur kalimat, kehematan kata, dan kelogisan penalaran. Kesalahan struktur kalimat pada penelitian ini berjumlah 770 atau 35\%. Kesalahan yang paling banyak pada kalimat efektif terdapat pada ketidakhematan pemakaian kata yang berjumlah 1346 atau 61\%. Kalimat yang tidak mempunyai kelogisan penalaran berjumlah 91 atau 4\%. Data penelitian pada 
kalimat efektif ini menunjukkan kesalahan penggunaan kalimat efektif merupakan kesalahan yang paling banyak dilakukan oleh mahasiswa dalam penulisan laporan tugas akhirnya, yaitu 2207 atau 100\%. Tabel berikut menunjukkan kesalahan penggunaan kalimat efektif yang dimaksud.

Tabel 8. Kesalahan Penggunaan Kalimat Efektif

\begin{tabular}{|l|l|l|l|}
\hline \multirow{2}{*}{ No. } & \multirow{2}{*}{$\begin{array}{l}\text { Aspek } \\
\text { Penggunaan } \\
\text { Kalimat Efektif }\end{array}$} & Kesalahan Penggunaan \\
\cline { 3 - 4 } & Jumlah & Persentase \\
\hline 1. & Struktur Kalimat & 770 & $35 \%$ \\
\hline 2. & Kehematan Kata & 1346 & $61 \%$ \\
\hline 3. & $\begin{array}{l}\text { Kelogisan } \\
\text { Penalaran }\end{array}$ & 91 & $4 \%$ \\
\hline 4. & Jumlah & 2207 & $100 \%$ \\
\hline
\end{tabular}

Penggunaan kalimat efektif pada penelitian ini dikaji berdasarkan tiga aspek yaitu struktur kalimat, kehematan kata, dan kelogisan penalaran. Hasil analisis menunjukkan kesalahan kalimat efektif merupakan kesalahan yang paling banyak dilakukan oleh mahasiswa Politeknik Negeri Padang dalam penulisan laporan tugas akhir. Ketepatan kalimat efektif mempunyai persentase $0 \%$ dengan kategori penggunaan bahasa sangat kurang. Kualitas penggunaan bahasa pada struktur kalimat berkategori kurang dengan persentase 33\%. Kehematan kata berkategori penggunaan sangat kurang dengan besar persentase 19\%. Kelogisan penalaran mempunyai kategori penggunaan bahasa cukup dengan persentase ketepatan 48\%. Selanjutnya, penulisan kalimat efektif dibahas secara terperinci sesuai dengan aspek kajian dengan menyertakan contoh kesalahan dan sekaligus perbaikannya.

Salah satu aspek yang dianalisis pada penulisan kalimat efektif adalah struktur kalimat yang digunakan oleh mahasiswa pada laporan tugas akhir. Sebuah kalimat dapat dikatakan lengkap apabila setidaknya terdiri dari pokok dan penjelas. Pokok dan penjelas yang dimaksudkan adalah subjek dan predikat. Kalimat dalam ragam resmi baik lisan maupun tulisan, paling sedikit harus memiliki subjek $(\mathrm{S})$ dan predikat $(\mathrm{P})$. Kalau tidak memiliki unsur subjek dan predikat, pernyataan itu bukanlah kalimat. Deretan kata yang seperti itu hanya dapat disebut frasa (Arifin, 2008:66). Selanjutnya, dalam Tata Bahasa Baku Bahasa Indonesia (Alwi, 2003:325) dijelaskan bahwa unsur sebuah kalimat ada unsur yang wajib dan ada unsur yang tidak wajib. Unsur yang wajib adalah unsur yang tidak dapat dihilangkan (SP), sedangkan unsur yang tidak wajib adalah unsur yang dapat dihilangkan tanpa mempengaruhi informasi 
penting yang ada dalam kalimat itu

Pada laporan tugas akhir mahasiswa Politeknik Negeri Padang ditemukan banyak kesalahan dalam penulisan struktur kalimat. Ketidakjelasan subjek dan predikat membuat kalimat menjadi tidak efektif. Kejelasan subjek dan predikat dapat dilakukan dengan menghindari pemakaian kata depan di, dalam, bagi, untuk, pada, sebagai, tentang, mengenai, menurut, dan sebagainya di depan subjek (Sugono, 2009:206). Kalimatkalimat yang digunakan tidak memiliki kelengkapan unsur minimal yaitu subjek dan predikat. Kesalahan-kesalahan yang dimaksud dapat dilihat pada kalimat berikut ini.

1) // Untuk memenuhi salah satu syarat lulus program Diploma III

$\mathrm{K}$

Politeknik Universitas Andalas Padang. // (1. M-01/2/10-11)

2) // Untuk memperoleh data-data dan informasi yang berkaitan dengan $\mathrm{K}$

hal-hal seperti, // pada proyek

Pembangunan Gedung Kantor Badan $\mathrm{K}$

Meteorologi dan Geofisika

Padangpanjang yang digunakan dalam

$\mathrm{K}$

penyusunan Tugas Akhir // adalah // sebagai berikut:

$\mathrm{P}$ (pelengkap)

(8. SP-02/3-4/27-28 \& 1-2)

Kalimat (1) dan (2) adalah pernyataanpernyataan yang tidak memenuhi syarat sebagai kalimat. Pernyataan-pernyataan yang dimaksud merupakan unsur keterangan yang cukup panjang. Kesalahan pada kalimat di atas dapat diperbaiki sebagai berikut.
1a) // Tugas akhir // ditulis // untuk

\section{S P}

Memenuhi salah satu syarat lulus Program Diploma III Politeknik Universitas Andalas Padang. (1. M-01/2/10-11)

2a) // Metode yang digunakan // $\mathrm{S}$ untuk memperoleh data dan informasi dalam penyusunan tugas akhir // adalah: ... //

$\mathrm{P}$

$$
\text { (8. SP-02/3-4/27-28 \& 1-2) }
$$

\section{Simpulan}

Hasil penelitian menunjukkan bahwa mahasiswa Politeknik Negeri Padang kurang mampu menggunakan bahasa baku pada laporan tugas akhir. Hal ini berimplikasi terhadap berbagai pihak, di antaranya mahasiswa, pembimbing laporan tugas akhir, dan pengajar mata kuliah bahasa Indonesia. Hal utama yang perlu dilakukan adalah perlunya upaya peningkatan kemampuan menulis mahasiswa khususnya untuk penulisan formal.

Usaha peningkatan kemampuan mahasiswa difokuskan pada penguasaan aspek-aspek kebahasaan khususnya ejaan, diksi, dan kalimat efektif. Kesalahankesalahan yang terdapat pada laporan tugas akhir dianalisis dan dijelaskan, sehingga mahasiswa mengetahui dan memahami penulisan yang benar sesuai kaidah. Di samping itu, mahasiswa hendaknya meningkatkan keterampilan dengan banyak berlatih untuk mengasah keterampilan menulis terutama kemampuan mengaplikasikan kaidah-kaidah kebahasaan. Latihan terus-menerus akan meningkatkan kemampuan dan keterampilan mahasiswa untuk mengemukakan gagasan dalam 
bentuk karya tulis ilmiah.

Pembimbing tugas akhir perlu menyadari bahwa penulisan formal membutuhkan kecermatan. Hal ini dapat dilakukan dengan memberikan pengarahan dan perhatian khusus pada penulisan yang dilakukan mahasiswa terutama untuk aspek kebahasaannya. Selanjutnya, pembimbing dituntut untuk memeriksa laporan tugas akhir yang ditulis oleh mahasiswa.

Pengajar mata kuliah bahasa Indonesia dapat lebih meningkatkan pemahaman mahasiswa terhadap aturanaturan penulisan (ejaan, diksi, dan kalimat efektif). Hal ini dapat dilakukan dengan memberikan penguasaan teori disertai latihan-latihan yang aplikatif dan berkesinambungan. Di samping itu, metode pembelajaran perlu dikemas dengan bervariasi dan menarik, sehingga materi yang disampaikan mudah dipahami dan tidakt membosankan.

\section{Daftar Rujukan}

Akhadiah, Sabarti. dkk. 1988. Pembinaan Kemampuan Menulis Bahasa Indonesia. Jakarta: Erlangga.

Alwi, Hasan. 2003. Tata Bahasa Baku Bahasa Indonesia. Edisi Ketiga. Jakarta: Balai Pustaka.

Arifin, E. Zaenal. dan S. Amran Tasai. 2008. Cermat Berbahasa Indonesia untuk Perguruan Tinggi. Edisi Revisi. Jakarta: Akademika Pressindo.

Arikunto, Suharsimi. 2009. Manajemen Penelitian. Jakarta: Rineka Cipta.

Atmazaki. 2009. Kiat-kiat Mengarang dan Menyunting. Edisi Kedua. Padang:

\section{UNP Press.}

Markhamah. 2000. "Bahasa dalam Penulisan Ilmiah". dalam Prayitno. Editor.

Pembudayaan Penulisan Karya Ilmiah. Surakarta: Muhammadiyah University

Maryadi . 2000. "Pengertian dan Kriteria Karya Ilmiah". dalam Prayitno. Editor. Pembudayaan Penulisan Karya Ilmiah. Surakarta: Muhammadiyah University Press.

Mustakim. 1994. Membina Kemampuan Berbahasa: Panduan ke Arah Kemahiran Berbahasa. Jakarta: Gramedia Pustaka Utama.

Peraturan Akademik Politeknik Negeri Padang. 2008. Keputusan Rektor Nomor 11593/J.16/TU/Unand/2008.

Pusat Pembinaan dan Pengembangan Bahasa. 1987. Pedoman Umum Ejaan Bahasa Indonesia yang Disempurnakan. Jakarta: Departemen Pendidikan dan Kebudayaan.

Ruskhan, Abdul Gaffar. 2007. Kompas Bahasa Indonesia. Jakarta: PT. Grasindo.

Semi, M. Atar. 2009. Menulis Efektif. Padang: UNP Press.

Sudjana. 1996. Metoda Statistika. Edisi ke-

6. Bandung: Tarsito.

Sudjana, Nana. dan Ibrahim. 2001.

Penelitian dan Penilaian Pendidikan. Cetakan Kedua. Bandung: Sinar Baru Algensindo Offset. 
Sugono, Dendy. 2009. Mahir Berbahasa

Indonesia dengan Benar. Jakarta:

Gramedia Pustaka Utama.

Suyanto. dan Asep Jihad. 2009. Betapa

Mudahnya Menulis Karya Ilmiah.

Yogyakarta: Eduka.

\section{Biodata Singkat}

Welsi Haslina lahir di Padang, 23

Maret 1970. Penulis menamatkan strata 1

(S1) di Fakultas Sastra Universitas Andalas pada tahun 1992 dan Strata 2 (S2) untuk gelar Magister Pendidikan (M.Pd) di Universitas Negeri Padang tahun 2011. Penulis menjadi staff pengajar di Politeknik Negeri Padang sejak tahun1993 sampai dengan sekarang. Penulis aktif ikut dalam kegiatan pertemuan ilmiah dan kegiatan akademik. Selain itu penulis juga aktif menulis di beberapa jurnal di bidangkebahasaan. 
Jurnal Bahasa, Sastra Indonesia, dan Pengajarannya Volume 2- Nomor 1, April 2019, (HIm 189-197)

Available online at: http://sasando.upstegal.ac.id 